\title{
矩形照射野コリメータ散乱係数に対する 等価正方形評侕法の検討
}

\author{
奈良鉄造·岩崎 晃 ${ }^{1)} \cdot$ 佐藤和彦 \\ 洞内美明・駒井史雄・福士英人
}

青森県立中央病院放射線科

1 ) 弘前大学医学部保健学科

\section{緒 叚}

高エネルギー光子ビーム照射ではファントム内の吸 収線量を一次線量と散乱線量とに分けて評価する場合 がある. 一次線量は線源から放出される光子と加速器 ヘッドから笴与する成分を含めた実効一次線とファン トム内で散乱した散乱成分とにより求められる。矢効 一次および散乱線量の分析には全散乱係数 $\left(S_{c p}\right), コ リ$ メータ散乱係数 $\left(S_{c}\right)$, ファントム散乱係数 $\left(S_{p}\right)$ を用い る方法がある(Holtら ${ }^{1)}$, Khanら ${ }^{2)}$ ).
コリメータ散乱係数 $\left(S_{c}\right)$ の測定では従来まではビル ドアップキャップを用いる方法が一般的であったが,

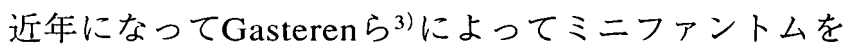
用いる方法が提唱された。線質指標 $(\mathrm{QI})^{4)}$ が $\mathrm{QI} \leqq 0.75$ (10MV以下のX線)の場合とQI>0.75(10MVを越えたX 線)の場合とに対して，いずれもピーク深に比してよ り深い測定深 (それぞれ $5 \mathrm{~cm}$ と $10 \mathrm{~cm}$ )が提案されてい る.この方法は混入電子の影響をなくすることがで き,さらに臨床上意味のある媣さでの測定情報が提供

\section{Comments on Evaluation Method for Equivalent Square Fields to the Colli- mator Scatter Factors of Rectangular Fields}

\section{TETSUZO NARA, AKIRA IWASAKI'), KAZUHIKO SATO, YOSHIAKI HORANAI, FUMIO KOMAI, and HIDETO FUKUSHI}

Department of Radiology. Aomori Prefectural Center Hospital

1) Hirosaki University School of Health Sciences

Received March 2, 2001; Revision accepted Feb. 21, 2002; Code No. 852

\section{Summary}

In the measurement of $4 \mathrm{MV}$ and $10 \mathrm{MV}$ X-ray collimator scatter factors $\left(S_{c}\right)$, the method of using an acrylic mini-phantom showed no significant differences between cases in which the chamber axis was either parallel or perpendicular to the beam axis. Chamber readings with an aluminum or acrylic build-up cap were not reflected by contaminant electrons when the chamber axis was parallel to the beam axis. On the basis of the data on $4 \mathrm{MV}$ and $10 \mathrm{MV}$ X-ray collimator $S_{c}$ measured using an acrylic mini-phantom, we examined three methods of obtaining square fields equivalent to rectangular fields, and reached the following conclusions: (1) The A/P method was not accurate because it did not take into account the structure of the radiation head. (2) Regarding the geometrical weight factor $(k)$ used in the field-mapping method, more accurate $k$ values were obtained when using the geometrical places of the flattening filter(or the second source, taken from the concept of extra-focal radiation), the upper and lower collimators, and the chamber, rather than when using the geometrical places of the source, the upper and lower collimators, and the chamber. (3) The most accurate $k$ values could, in general, be obtained when determined on the basis of measured $S_{c}$ data.

Key words: Collimator scatter factor, Mini-phantom, Collimator exchange effect, Field mapping method 
できる利点がある。

中川ら5)はアクリル製ミニファントムとアクリル製 ビルドアップキャップを用いて，X線ビーム軸に対す る検出器挿入方向(平行および垂直)の依存性について 報告している。コリメータ散乱係数 $\left(S_{c}\right)$ に関して，コ リメータ(上下段コリメータ)の作る矩形照射野におい て短辺と長辺の差が大きい場合に上下段コリメータの 開口度を逆にしたとき，X線出力が変化するコリメー 夕反転効果 (collimator exchange effect)の起こること が知られている。中田6)や保科7)はコリメータ反転効 果を効果的に検出する方法として，Kimら ${ }^{8)}$ の照射野 マッピング法を紹介している．この方法では検出器か ら線源側を見た場合の上下段コリメータで形成される 矩形照射野を等価正方形照射野に変換する手順をと る.なお，電子線の可変コリメータに関して，森川 がすでにこの方法を発表している。森川の式はKimら の式と同じ関数形になっていることに注目したい.

小照射野に対して検出器サイズの大きさが問題にな ることがある。この場合，電離箱軸をX線ビーム軸に 対して平行にさせることがある。この論文では検出器 のX線ビーム軸に対する挿入方向を再検討し，照射野 マッピング法の精度を調べた。 また照射野マッピング 法で用いる $k$ 值を最適に決める方法も提案する.

\section{1. 理論の背景}

1-1 全散乱係数 $\left(S_{c p}\right)$,コリメータ散乱係数 $\left(S_{c}\right)$, ファ ントム散乱係数 $\left(S_{p}\right)$

全散乱係数 $\left(S_{c p}\right)$, コリメータ散乱係数 $\left(S_{c}\right)$,ファント

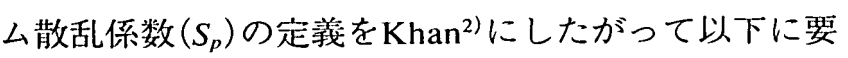
約する.

水ファントム内でのX線ビーム軸上に基隼深 $\left(d_{r}\right)$ を 設定する[この基準深は任意でよいが，この諭文では ピーク線量を示す深さ (ピーク深)を採用した].まず 基準深での吸収線量 $\left(D_{t}\right)$ を用いて全散乱係数 $\left(S_{c p}\right)$ を次 式で定義する。

$$
S_{c p}(A)=D_{t}\left(d_{r}, A\right) / D_{t}\left(d_{r}, 10 \times 10\right)
$$

ここで，Aは基準深での正方形または矩形照射野であ

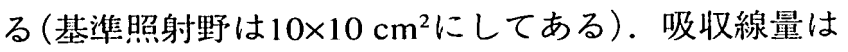
$\mathrm{X}$ 線出力に強く関係するので, X線出力の相対值を次 式のコリメー夕散乱係数 $\left(S_{c}\right)$ で評価する.

$$
S_{c}(A)=D_{\text {air }}(A) / D_{\text {air }}(10 \times 10)
$$

ここで， $\mathrm{D}_{\mathrm{air}}$ はミニファントムあるいはビルドアップ キャップを用いて得られる空中線量である.ファント 么散乱係数 $\left(S_{p}\right)$ は次式で定義する.

$$
S_{p}(A)=S_{c p}(A) / S_{c}(A)
$$

ファントム散乱係数 $S_{p}(\boldsymbol{A})$ は，基準深 $\left(d_{r}\right)$ において照射 野 $10 \times 10 \mathrm{~cm}^{2}$ のX線出力で得られる照射野 $A$ での吸収線 量と照射野 $10 \times 10 \mathrm{~cm}^{2}$ での吸収線量の比を表すことに なる $\left(S_{p}(10 \times 10)=1\right)$ ．この場合，側方電子平衡下での 実効一次吸収線量は照射野 $(A)$ に関係せず一定であ り，照射野 $(A)$ の変化によって生じるファントム散乱 係数 $\left(S_{p}\right)$ の変化は散乱線量のみの違いになる。ただ し，上記において少なくてもX線ビーム軸(コリメー 夕回転軸)近傍では，入射X線スペクトルは照射野サ イズによって変化しないものと仮定している。また基 準深 $\left(d_{r}\right)$ では，混入電子の影響がないことが理想的で ある。

\section{1-2 幾何学的加重係数 $(k)$}

$\operatorname{Kim} 5^{8)}$ は上下段コリメータの幾何学的配置により 矩形照射野を等価正方形照射野に変換する方法を発表

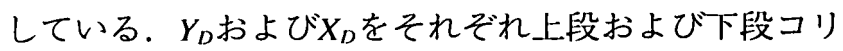
メータ絞りで得られる検出器位置での矩形照射野辺と すると, 検出器面での等価正方形照射野辺 $\left(S_{D}^{e q}\right)$ は次式 で表わされる(Fig. 1参照).

$$
S_{D}^{e q}=\left((1+k) X_{D} \cdot Y_{D}\right) /\left(k \cdot X_{D}+Y_{D}\right)
$$

ここで, $k$ は幾何学的加重係数で

$$
k=\left(L_{1 x} / L_{2 x}\right) \cdot\left(L_{2 y} / L_{1 y}\right)
$$

となる。ここで， $L_{1 y}$ および $L_{1 x}$ は上段および下段コリ メー夕上端と線源面間距離， $L_{2 y}$ および $L_{2 . x}$ は上段およ び下段コリメータ上端と検出器面間距離である.

$\mathrm{A} / \mathrm{P}$ 法で等価正方形照射野を得る式は(4)式で $k=1$ と した場合であり，

$$
S_{D}^{e q}=\left(2 X_{D} \cdot Y_{D}\right) /\left(X_{D}+Y_{D}\right)
$$

となる。

\section{2. 実験方法}

実験には4MVおよび10MV X線が発生する三菱電 機株式会社製直線電子加速装置 (EXL-15DP)を使用し た.上下段コリメータ（Y，X)のモ二タ電離箱に与え る影響は,この論文で取り扱っている項目に関しては 付録Aに記述しているように一般に無視できる。

\section{2-1 コリメータ散乱係数 $\left(S_{c}\right)$ の測定における検出器 方向依存性}

ミニファントムには $4 \mathrm{MV}$ と $10 \mathrm{MVX}$ 線双方に対し てアクリル製の円筒形ファントム (直径 $4 \mathrm{~cm}$, 高さ 10 $\mathrm{cm}$, 测定深 $5 \mathrm{~cm}$ )を使用した. ビルドアップキャップ にはアクリル製キャップ(4MVX線用：外径 $2.4 \mathrm{~cm}$, 厚さ $0.99 \mathrm{~g} / \mathrm{cm}^{2}, 10 \mathrm{MV}$ X線用:外径 $4.9 \mathrm{~cm}$, 厚さ $2.48 \mathrm{~g} /$ 
$\left.\mathrm{cm}^{2}\right)$ とアルミ製キャップ(4MV X線用: 外径 $1.45 \mathrm{~cm}$, 厚さ $0.97 \mathrm{~g} / \mathrm{cm}^{2}, 10 \mathrm{MV} \mathrm{X}$ 線用: 外径 $2.73 \mathrm{~cm}$, 厚さ $2.88 \mathrm{~g} /$ $\left.\mathrm{cm}^{2}\right)$ を使用した。

検出器にはPTW社製モデルW23333の0.6 $\mathrm{cm}^{3}$ 指頭型 電離箱 $($ 電離容積 $0.61 \mathrm{~cm} \Phi \times 2.07 \mathrm{~cm}$ )を使用し，その電 位計にはIonex dose master 2590 (NE Technology)を 用いた。 なお， 線源検出器間距離 $(\mathrm{SCD})$ は $100 \mathrm{~cm}$ であ る。

ミニファントム(アクリル製)あるいはビルドアップ キャップ(アルミ製およびアクリル製)を用いて，X線 ビーム軸に対して検出器軸を (a) 平行に置いた場合, (b)垂直に置いた場合の配置をFig. 2に表わす（なお， ミニファントム軸はX線ビーム軸に対して常に平行に している).

\section{2-2 コリメータ反転効果}

コリメータ反転効果に関しては面積周囲長比法 (A/ P法)と照射野マッピング法で行った，ただし，照射野 マッピング法においては, (a) 線源/上下段コリメー夕। 検出器の位置関係から幾何学的荷重係数 $(k)$ を求める 場合について, (b) 平坦化フイルタ/上下段コリメータ/ 検出器の位置関係から幾何学的荷重係数 $(k)$ を求める 場合について, (c)コリメー夕散乱係数 $\left(S_{c}\right)$ の測定デー 夕に基づいて幾何学的加重係数 $(k)$ を求める場合につ いてそれぞれコリメータ反転効果精度を調べた.

Kimらの方法による幾何学的加重係数の $k$ 值は式 (5) により， $k=1.543$ となる $\left(L_{1 x}=336.67 \mathrm{~mm}\right.$, $\left.L_{2 x}=663.33 \mathrm{~mm}, L_{1 y}=247.55 \mathrm{~mm}, L_{2 y}=752.425 \mathrm{~mm}\right)$. コ リメータ反転効果に関する測定ではミニファントム (アクリル製)を用いて，X線ビーム軸と検出器軸とを 平行にさせて行った。この場合の検出器位置における 矩形照射野辺は上下段コリメータによりそれぞれ5〜 $40 \mathrm{~cm}$ にした。

\section{3. 結果および考察}

\section{3-1 検出器の方向依存性}

4MV X線に対しては、ミニファントム(アクリル 製)，アルミ製ビルドアップキャップおよびアクリル 製ビルドアップキャップを用いて，X線ビーム軸に対 して検出器軸が $(a)$ 平行および $(b)$ 垂直に置かれた場合 (Fig. 2参照)の正方形照射野コリメー夕散乱係数 $\left(S_{c}\right)$ を それぞれTable 1(a)，（b)に示す.

Table 1 (a)に示すように, 検出器軸をX線ビーム軸 に対して平行に置いた場合，ミニファントム使用に対 するアクリル製ビルドアップキャップ使用での相対誤 差は $0 \%$ \%から+0.5\%に収まっている。またミニファン トム使用に対するアルミ製ビルドアップキャップ使用 での相対誤差は-0.1\%から+0.3\%に収まっている.

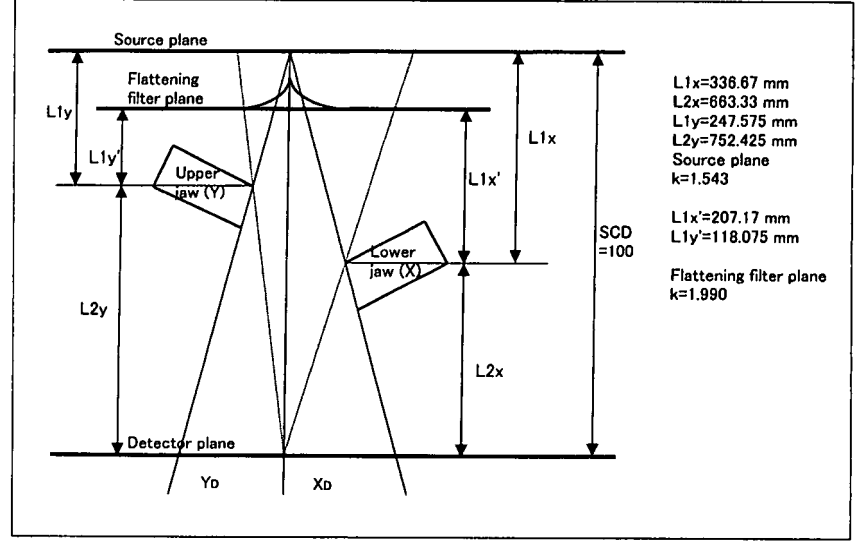

Fig. 1 Schematic diagram showing geometric relationship between the detector and the jaw collimators. Also shown are the field sizes projected on the source and detector planes.

Table 1(b)に示すように，検出器軸をX線ビーム軸 に対して垂直に置いた場合，ミニファントム使用に対 するアクリル製ビルドアップキャップ使用での相対誤 差は-0.4\%から+0.9\%収まっている。またミニファン トム使用に対するアルミ製ビルドアップキャップ使用 での相対誤差は $0 \%$ から+0.6\%に収まっている.

ミニファントム使用では，検出器軸をX線ビーム軸 に対して平行および垂直に置いた場合でもその間に有 意な差が見られなかった。これにより，ミニファント ム使用では混入電子による影響がなくなることが理解 される。

アルミ製およびアクリル製ビルドアップ使用に関し ては，検出器軸をX線ビーム軸に対して平行に置く場 合より，垂直に置く場合の方が $10 \times 10 \mathrm{~cm}^{2}$ 以上で全体 的に少し大きい值を示すことが理解される。この現象 は混入電子による影響3)と思われる.

Fryeら ${ }^{10)}$ によると, ビルドアップキャップとミニフ アントムによる測定結果では，4MV X線でその差は $0.5 \%$ 以内で一致している，混入電子の影響の程度は ビルドアップキャップのわずかな厚さの変化，照射へ ッド内部構造の違いによって大きく左右されることが 理解される。 なお，Khanら2)は $4 \mathrm{MVX}$ X線に対して, Plexiglas製とアルミ製ビルドアップキャップによる測 定結果には有意な差がないと報告している。

Table 2(a)，（b) は，10MV X線に対するコリメータ 散乱係数 $\left(S_{c}\right)$ を表す. ミニファントム使用では $4 \mathrm{MV} \mathrm{X}$ 線の場合と同様に検出器軸をX線ビーム軸に対して,

(a)平行および(b) 垂直に置いた場合 (Fig. 2参照)とも ほとんど同じ結果になった。検出器軸をX線ビーム軸 に対して平行に配置した場合，ミニファントム使用 とアルミ製・アクリル製ビルドアップキャップ使用間 で有意な差はなかった。しかし，検出器軸をX線ビー ム軸に対して垂直に配置した場合，ミニファントム使 
Table 1 Sets of $4 \mathrm{MV} X$-ray collimator scatter factors $\left(S_{c}\right)$ obtained using an acrylic mini-phantom, an aluminum build-up cap, and an acrylic build-up cap. The chamber axis is (a) parallel and (b) perpendicular to the beam axis.

(a) Parallel

\begin{tabular}{lccccccccccccccccc}
\hline \hline & \multicolumn{110}{c}{ Side of square field $(\mathrm{cm})$ at SCD $100 \mathrm{~cm}$} \\
\cline { 2 - 15 } & 5 & 6 & 7 & 8 & 9 & 10 & 12 & 14 & 16 & 18 & 20 & 24 & 28 & 32 & 36 & 40 \\
\hline Mini & 0.975 & 0.981 & 0.987 & 0.992 & 0.996 & 1.000 & 1.004 & 1.008 & 1.009 & 1.012 & 1.013 & 1.016 & 1.019 & 1.021 & 1.024 & 1.026 \\
Al & 0.975 & 0.982 & 0.987 & 0.991 & 0.996 & 1.000 & 1.005 & 1.007 & 1.009 & 1.011 & 1.014 & 1.016 & 1.020 & 1.024 & 1.026 & 1.027 \\
Acry & 0.976 & 0.983 & 0.989 & 0.994 & 0.997 & 1.000 & 1.005 & 1.008 & 1.010 & 1.013 & 1.015 & 1.019 & 1.023 & 1.025 & 1.025 & 1.027 \\
\hline
\end{tabular}

(b) Perpendicular

\begin{tabular}{lccccccccccccccccc}
\hline \hline & \multicolumn{110}{c}{ Side of square field (cm) at SCD 100cm } \\
\cline { 2 - 14 } & 5 & 6 & 7 & 8 & 9 & 10 & 12 & 14 & 16 & 18 & 20 & 24 & 28 & 32 & 36 & 40 \\
\hline Mini & 0.975 & 0.981 & 0.988 & 0.993 & 0.996 & 1.000 & 1.004 & 1.008 & 1.011 & 1.012 & 1.014 & 1.019 & 1.021 & 1.023 & 1.024 & 1.025 \\
Al & 0.975 & 0.981 & 0.989 & 0.993 & 0.997 & 1.000 & 1.005 & 1.009 & 1.013 & 1.015 & 1.017 & 1.022 & 1.026 & 1.028 & 1.030 & 1.031 \\
Acry & 0.971 & 0.979 & 0.986 & 0.991 & 0.996 & 1.000 & 1.005 & 1.009 & 1.012 & 1.015 & 1.018 & 1.023 & 1.026 & 1.030 & 1.032 & 1.034 \\
\hline
\end{tabular}

Table 2 Sets of $10 \mathrm{MV} X$-ray collimator scatter factors $\left(S_{c}\right)$ obtained using an acrylic mini-phantom, an aluminum build-up cap, and an acrylic build-up cap. The chamber axis is (a)parallel and (b) perpendicular to the beam axis.

(a) Parallel

\begin{tabular}{lccccccccccccccccc}
\hline \hline & \multicolumn{110}{c}{ Side of square field $(\mathrm{cm})$ at SCD $100 \mathrm{~cm}$} \\
\cline { 2 - 14 } & 5 & 6 & 7 & 8 & 9 & 10 & 12 & 14 & 16 & 18 & 20 & 24 & 28 & 32 & 36 & 40 \\
\hline Mini & 0.968 & 0.978 & 0.984 & 0.990 & 0.997 & 1.000 & 1.007 & 1.011 & 1.015 & 1.018 & 1.020 & 1.026 & 1.029 & 1.032 & 1.035 & 1.036 \\
Al & 0.968 & 0.978 & 0.985 & 0.991 & 0.996 & 1.000 & 1.006 & 1.011 & 1.016 & 1.018 & 1.021 & 1.027 & 1.029 & 1.033 & 1.035 & 1.036 \\
Acry & 0.963 & 0.977 & 0.984 & 0.989 & 0.995 & 1.000 & 1.008 & 1.013 & 1.017 & 1.021 & 1.024 & 1.028 & 1.034 & 1.036 & 1.039 & 1.040 \\
\hline
\end{tabular}

(b) Perpendicular

\begin{tabular}{|c|c|c|c|c|c|c|c|c|c|c|c|c|c|c|c|c|}
\hline \multicolumn{17}{|c|}{ Side of square field $(\mathrm{cm})$ at $S C D 100 \mathrm{~cm}$} \\
\hline & 5 & 6 & 7 & 8 & 9 & 10 & 12 & 14 & 16 & 18 & 20 & 24 & 28 & 32 & 36 & 40 \\
\hline Mini & 0.968 & 0.976 & 0.984 & 0.990 & 0.996 & 1.000 & 1.007 & 1.012 & 1.016 & 1.019 & 1.022 & 1.028 & 1.031 & 1.033 & 1.037 & 1.038 \\
\hline Al & 0.963 & 0.972 & 0.982 & 0.989 & 0.996 & 1.000 & 1.009 & 1.013 & 1.020 & 1.023 & 1.027 & 1.029 & 1.037 & 1.041 & 1.043 & 1.046 \\
\hline Acry & 0.962 & 0.973 & 0.982 & 0.990 & 0.996 & 1.000 & 1.010 & 1.016 & 1.021 & 1.025 & 1.029 & 1.035 & 1.039 & 1.042 & 1.044 & 1.045 \\
\hline
\end{tabular}

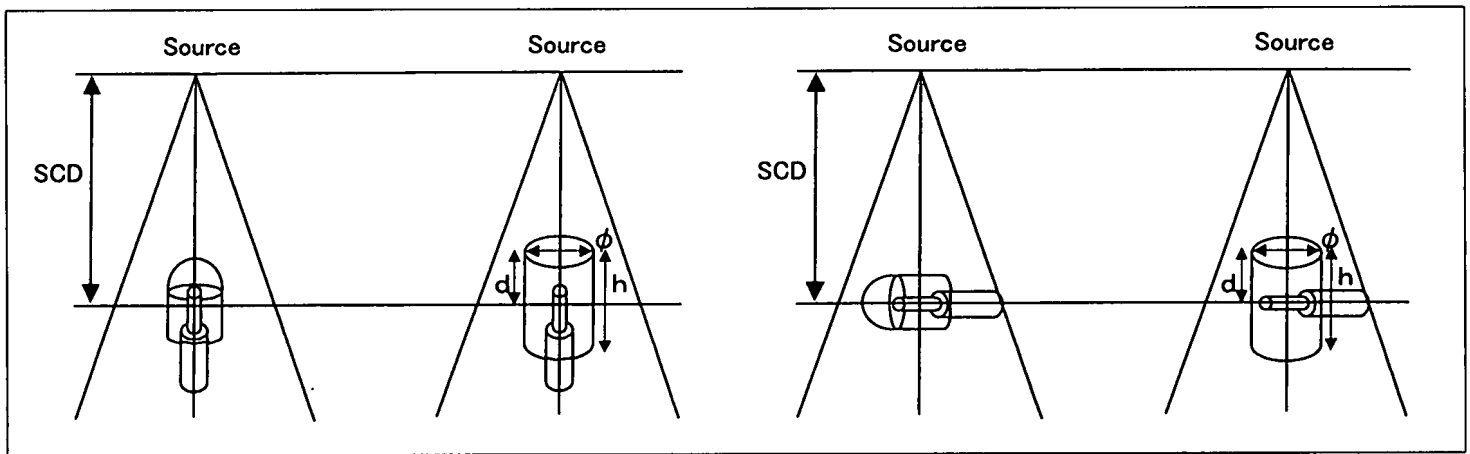

Fig. 2 Irradiation geometries for the measurement of collimator scatter factors $\left(S_{c}\right)$ using a mini-phantom and build-up cap.

(a) The chamber axis is parallel and (b) perpendicular to the beam axis. 
用とアルミ製・アクリル製ビルドアップキャップ使用 間で最大 $0.9 \% の$ 差が生じた。これはアルミ製・アク リル製ビルドアップキャップの使用においては，線源 側からみてX線ビーム軸に対して検出器軸を平行ある いは垂直に置いた場合とでは，ビルドアップキャップ の形状が変わり，それによって混入電子3による影響 の違いが反映されたものと推測する。

保科7の結果では10MV X線の場合, 正方形照射野 $20 \times 20 \mathrm{~cm}^{2}$ を超えると, ミニファントム使用とビルド アップキャップ使用間において 1 \%以上の差を検出し ている.この現象は照射へッド内からの混入電子の影 響がビルドアップキャップを用いた場合に反映されて いると結論し, 混入電子の影響を受けないミニファン トム使用の利点を強調している．われわれの測定結果 では $1 \%$ 以上を超えることはなかった。混入電子によ る影響の程度は照射へッドの構造に大きく依存するこ とに注目しなければならない。

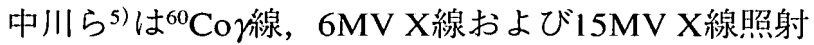
において、ミニファントム使用ではX線ビーム軸に対し て検出器軸の挿入方何の違いによるコリメー夕散乱係 数 $\left(S_{c}\right)$ への影響は哭視できると報告している．われわ れの結果でもX線エネルギー $4 \mathrm{MV}, 10 \mathrm{MVX}$ X線でこの ことが確認された。

\section{3-2 コリメータ反転効果}

コリメータ反転効果に関する測定はすべてミニファ ントム(アクリル製)を用いて, 検出器軸をX線ビーム 軸に対して平行に配置して行った. Table 3，4はそれ ぞれ 4MV，10MV X線に対する矩形照射野コリメー 夕散乱係数 $\left(S_{c}\right)$ を表わす。

等価正方形への変換はA/P法と照射野マッピング法 で行った。なお，照射野マッピング法では上下段コリ メータなどの幾何学的配置より決めた $k$ 值 (幾何学的荷 重係数)を用いる方法と $k$ 值を実測した矩形照射野コリ メータ散乱係数 $\left(S_{c}\right)$ に基づいて決定する方法とを採用 した.

4MVおよび10MV X線に関して, Table 3，4での矩 形照射野コリメー夕散乱係数 $\left(S_{c}\right)$ を $\mathrm{A} / \mathrm{P}$ 法 ( (6) 式)によ って変換した等価正方形照射野をそれぞれFig. $3(\mathrm{a})$ お よびFig. 3(b)に示す。黑三角 (A) は正方形照射野コリ メ一夕散乱係数 $\left(S_{c}\right)$ の測定值を示す。㿤線はそれらを 正方形照射野辺に関して五次多項式で表わしたもので ある。

4MVX線の場合，実線で示した正方形照射野コリメ 一夕散乱係数 $\left(S_{c}\right)$ に対して等価照射野変換後のコリメ ー夕散乱係数 $\left(S_{c}\right)$ の相対誤差は-0.59\%から+1.17\%に 分布している．他方，10MV X線の場合．実線の正方 形照射野コリメー夕散乱係数 $\left(S_{c}\right)$ に対して等佂照射野
変換後のコリメー夕散乱係数 $\left(S_{c}\right)$ の相対䛊差は-1.23\% から+1.35\%に分布している.いずれの場合でもかな り大きな鿁差になっている。

線源, 絞り機構および検出器の幾何学的位置関係か ら求めた照射野マッピング法による結果は，4MVおよ び10MV X線に関してそれぞれFig. 4 (a)およびFig. 4, (b)に表す． $k$ 值には前述の $k=1.543$ を朋いている. 4 MVX線の場合には実線で示した正方形照射野コリメ 一夕散乱係数 $\left(S_{c}\right)$ に対して, 等洒照射野变換後のコリ メー夕散乱係数 $\left(S_{c}\right)$ の相対䛊差は-0.32\%から+0.62\% に分布している．他方，10MVX線の場合には，実線 で示した正方形照射野コリメー夕散乱係数 $\left(S_{c}\right)$ に対し て等洒照射野変換後のコリメータ散乱係数 $\left(S_{c}\right)$ の相対 誤差は-0.61\%から+0.81\%に分布している。

保科7)はコリメータ反転効果による影響をKim $5^{8) の ~}$ 照射野マッピングでは確実に解消し切れないと報告し ているが，このことはわれわれの結果と一致する.

KimらかX線照射に対して理論的考察で得た(4)式はす でに1993年にVadashとBjängard ${ }^{11)} に よ り$ 経験的に得ら れている。この場合 $k$ 值を次のように設定した。

一連の矩形照射野 $\left(X_{D}, Y_{D}\right)$ に対して，あらかじめコ リメータ散乱係数 $\left(S_{c}\right)$ を実測して置く.なお，正方形 照射野で得たコリメータ散乱係数 $\left(S_{c}\right)$ を別にグラフ化 しておく，次にある $k$ 值を用い(4)式によりある一つの 矩形照射野 $\left(X_{D}, Y_{D}\right)$ に対して得た等価正方形照射野 $\left(S_{D}^{e q}\right)$ に対する $S_{c}$ 值をグラフ化したコリメータ散乱係数 $\left(S_{c}\right)$ デー夕より求める。この $S_{c}$ 值と実測 $S_{c}$ 值との差の 絶対值を求める。このことを一連の矩形照射野 $\left(X_{D}\right.$, $\left.Y_{D}\right)$ について行い差の絶対值の和をつくる. 最適な $\mathrm{k}$ 值 はその和が最小な場合であるとした。

われわれは上記において「差の自乗和」を使用した。 この場合の方が全体的により小さな正負の最大相対誤 差が得られることが判明したからである。

この方法で求めた幾何学的荷重係数 $(k)$ は $4 \mathrm{MV} \mathrm{X}$ 線 では $k=2.103$ となり，10MV X線では $k=2.280$ となっ た.これらの $k$ 值を $4 \mathrm{MV}$ および10MV X線のコリメー 夕散乱係数 $\left(S_{c}\right)$ (Table 3，4)に適用した場合の結果を それぞれFig. 5 (a)およびFig. 5(b)に表す.

4MV X線の場合には，実線で示した正方形照射野コ リメータ散乱係数 $\left(S_{c}\right)$ に対して等価照射野変換後のコ リメー夕散乱係数 $\left(S_{c}\right)$ の相対鿁差は-0.31\%から+0.46 \%に分布している，他方，10MV X線の場合には,実線 の正方形照射野コリメー夕散乱係数 $\left(S_{c}\right)$ に対して等価 照射野変換後のコリメー夕散乱係数 $\left(S_{c}\right)$ の相対誤差 は-0.23\%から+0.41\%に分布している．前述の二つの 方法(A/P法， $k=1.543$ を使用した照射野マッピング法) に比べてかなり高い精度が得られた。

照射ヘッド内の構造物（一次コリメータ，上下段コ 
Table $34 \mathrm{MV} X$-ray collimator scatter factors $\left(S_{c}\right)$ measured using the mini-phantom method for rectangular fields produced by the upper and lower collimators.

\begin{tabular}{|c|c|c|c|c|c|c|c|c|c|c|c|c|c|c|c|c|}
\hline \multirow{2}{*}{$\begin{array}{l}\text { Upper } \\
\text { jaw } \\
\text { (cm) }\end{array}$} & \multicolumn{16}{|c|}{ Lower jam $(\mathrm{cm})$} \\
\hline & 5 & 6 & 7 & 8 & 9 & 10 & 12 & 14 & 16 & 18 & 20 & 24 & 28 & 32 & 36 & 40 \\
\hline 5 & 0.975 & 0.977 & 0.978 & 0.980 & 0.980 & 0.981 & 0.982 & 0.982 & 0.983 & 0.983 & 0.983 & 0.983 & 0.983 & 0.984 & 0.984 & 0.984 \\
\hline 6 & 0.978 & 0.981 & 0.983 & 0.984 & 0.985 & 0.986 & 0.988 & 0.989 & 0.989 & 0.989 & 0.990 & 0.990 & 0.989 & 0.990 & 0.990 & 0.990 \\
\hline 7 & 0.982 & 0.985 & 0.987 & 0.989 & 0.990 & 0.992 & 0.992 & 0.994 & 0.994 & 0.994 & 0.994 & 0.994 & 0.994 & 0.994 & 0.995 & 0.995 \\
\hline 8 & 0.984 & 0.988 & 0.991 & 0.992 & 0.993 & 0.994 & 0.995 & 0.996 & 0.996 & 0.997 & 0.997 & 0.997 & 0.997 & 0.997 & 0.998 & 0.998 \\
\hline 9 & 0.987 & 0.991 & 0.993 & 0.994 & 0.996 & 0.997 & 0.998 & 0.999 & 0.999 & 0.999 & 1.000 & 1.000 & 1.001 & 1.001 & 1.002 & 1.002 \\
\hline 10 & 0.989 & 0.992 & 0.995 & 0.997 & 0.998 & 1.000 & 1.000 & 1.002 & 1.002 & 1.002 & 1.002 & 1.002 & 1.003 & 1.004 & 1.004 & 1.005 \\
\hline 12 & 0.991 & 0.996 & 0.998 & 1.000 & 1.001 & 1.003 & 1.004 & 1.004 & 1.005 & 1.005 & 1.005 & 1.006 & 1.007 & 1.008 & 1.009 & 1.010 \\
\hline 14 & 0.994 & 0.998 & 1.001 & 1.002 & 1.004 & 1.005 & 1.006 & 1.008 & 1.007 & 1.009 & 1.008 & 1.008 & 1.009 & 1.009 & 1.010 & 1.014 \\
\hline 16 & 0.995 & 0.999 & 1.002 & 1.003 & 1.004 & 1.006 & 1.007 & 1.009 & 1.009 & 1.010 & 1.010 & 1.011 & 1.012 & 1.013 & 1.014 & 1.015 \\
\hline 18 & 0.996 & 1.000 & 1.003 & 1.004 & 1.006 & 1.007 & 1.010 & 1.011 & 1.011 & 1.012 & 1.012 & 1.012 & 1.013 & 1.013 & 1.015 & 1.017 \\
\hline 20 & 0.996 & 1.000 & 1.003 & 1.005 & 1.007 & 1.008 & 1.010 & 1.012 & 1.012 & 1.013 & 1.013 & 1.015 & 1.014 & 1.017 & 1.018 & 1.019 \\
\hline 24 & 0.998 & 1.001 & 1.004 & 1.006 & 1.008 & 1.009 & 1.011 & 1.013 & 1.014 & 1.014 & 1.015 & 1.016 & 1.017 & 1.017 & 1.021 & 1.021 \\
\hline 28 & 0.998 & 1.002 & 1.005 & 1.007 & 1.009 & 1.011 & 1.013 & 1.014 & 1.015 & 1.016 & 1.016 & 1.017 & 1.019 & 1.020 & 1.022 & 1.023 \\
\hline 32 & 0.999 & 1.003 & 1.007 & 1.008 & 1.011 & 1.012 & 1.014 & 1.016 & 1.016 & 1.017 & 1.018 & 1.018 & 1.020 & 1.021 & 1.023 & 1.024 \\
\hline 36 & 1.000 & 1.004 & 1.007 & 1.010 & 1.012 & 1.014 & 1.016 & 1.017 & 1.018 & 1.018 & 1.019 & 1.020 & 1.021 & 1.023 & 1.024 & 1.025 \\
\hline 40 & 1.001 & 1.005 & 1.009 & 1.011 & 1.013 & 1.015 & 1.017 & 1.018 & 1.019 & 1.019 & 1.020 & 1.021 & 1.022 & 1.024 & 1.025 & 1.026 \\
\hline
\end{tabular}

Detector:PTW W23333 $0.6 \mathrm{~cm}^{3}$ thimble ionization chamber

Table $410 \mathrm{MV}$ X-ray collimator scatter factors $\left(S_{c}\right)$ measured using the mini-phantom method for rectangular fields produced by the upper and lower collimators.

\begin{tabular}{|c|c|c|c|c|c|c|c|c|c|c|c|c|c|c|c|c|}
\hline \multirow{2}{*}{$\begin{array}{l}\text { Upper } \\
\text { jaw } \\
\text { (cm) }\end{array}$} & \multicolumn{16}{|c|}{ Lower jam $(\mathrm{cm})$} \\
\hline & 5 & 6 & 7 & 8 & 9 & 10 & 12 & 14 & 16 & 18 & 20 & 24 & 28 & 32 & 36 & 40 \\
\hline 5 & 0.968 & 0.972 & 0.974 & 0.975 & 0.976 & 0.977 & 0.978 & 0.979 & 0.980 & 0.981 & 0.981 & 0.982 & 0.982 & 0.983 & 0.983 & 0.983 \\
\hline 6 & 0.973 & 0.978 & 0.980 & 0.981 & 0.983 & 0.984 & 0.986 & 0.985 & 0.986 & 0.987 & 0.986 & 0.989 & 0.989 & 0.990 & 0.990 & 0.989 \\
\hline 7 & 0.977 & 0.983 & 0.984 & 0.985 & 0.988 & 0.989 & 0.991 & 0.991 & 0.992 & 0.992 & 0.992 & 0.994 & 0.995 & 0.995 & 0.996 & 0.995 \\
\hline 8 & 0.981 & 0.986 & 0.988 & 0.990 & 0.993 & 0.993 & 0.995 & 0.995 & 0.997 & 0.997 & 0.997 & 0.998 & 0.999 & 0.999 & 1.000 & 1.000 \\
\hline 9 & 0.984 & 0.990 & 0.992 & 0.992 & 0.997 & 0.997 & 0.999 & 0.999 & 1.000 & 1.000 & 1.001 & 1.002 & 1.004 & 1.003 & 1.004 & 1.004 \\
\hline 10 & 0.987 & 0.992 & 0.995 & 0.995 & 1.000 & 1.000 & 1.002 & 1.003 & 1.004 & 1.003 & 1.004 & 1.005 & 1.008 & 1.007 & 1.008 & 1.008 \\
\hline 12 & 0.991 & 0.996 & 0.999 & 1.000 & 1.003 & 1.005 & 1.007 & 1.007 & 1.009 & 1.008 & 1.009 & 1.011 & 1.013 & 1.013 & 1.014 & 1.013 \\
\hline 14 & 0.993 & 0.999 & 1.002 & 1.003 & 1.007 & 1.008 & 1.011 & 1.011 & 1.012 & 1.012 & 1.013 & 1.015 & 1.017 & 1.017 & 1.018 & 1.018 \\
\hline 16 & 0.996 & 1.002 & 1.004 & 1.006 & 1.009 & 1.009 & 1.013 & 1.014 & 1.015 & 1.015 & 1.016 & 1.018 & 1.020 & 1.020 & 1.021 & 1.021 \\
\hline 18 & 0.997 & 1.003 & 1.006 & 1.007 & 1.010 & 1.012 & 1.015 & 1.016 & 1.017 & 1.018 & 1.019 & 1.021 & 1.022 & 1.022 & 1.024 & 1.023 \\
\hline 20 & 0.999 & 1.004 & 1.008 & 1.009 & 1.012 & 1.014 & 1.017 & 1.018 & 1.018 & 1.019 & 1.020 & 1.023 & 1.024 & 1024 & 1.026 & 1.025 \\
\hline 24 & 1.001 & 1.007 & 1.010 & 1.011 & 1.014 & 1.016 & 1.019 & 1.020 & 1.020 & 1.021 & 1.023 & 1.026 & 1.027 & 1.027 & 1.029 & 1.029 \\
\hline 28 & 1.003 & 1.008 & 1.012 & 1.013 & 1.016 & 1.018 & 1.021 & 1.022 & 1.023 & 1.024 & 1.025 & 1.028 & 1.029 & 1.029 & 1.031 & 1.031 \\
\hline 32 & 1.005 & 1.009 & 1.013 & 1.016 & 1.018 & 1.020 & 1.023 & 1.025 & 1.026 & 1.027 & 1.029 & 1.030 & 1.032 & 1.031 & 1.033 & 1.032 \\
\hline 36 & 1.006 & 1.012 & 1.015 & 1.018 & 1.019 & 1.022 & 1.025 & 1.026 & 1.027 & 1.028 & 1.030 & 1.033 & 1.034 & 1.033 & 1.034 & 1.034 \\
\hline 40 & 1.008 & 1.014 & 1.016 & 1.020 & 1.021 & 1.023 & 1.026 & 1.028 & 1.030 & 1.031 & 1.032 & 1.033 & 1.035 & 1.035 & 1.036 & 1.036 \\
\hline
\end{tabular}

Detector:PTW W23333 $0.6 \mathrm{~cm}^{3}$ thimble ionization chamber 

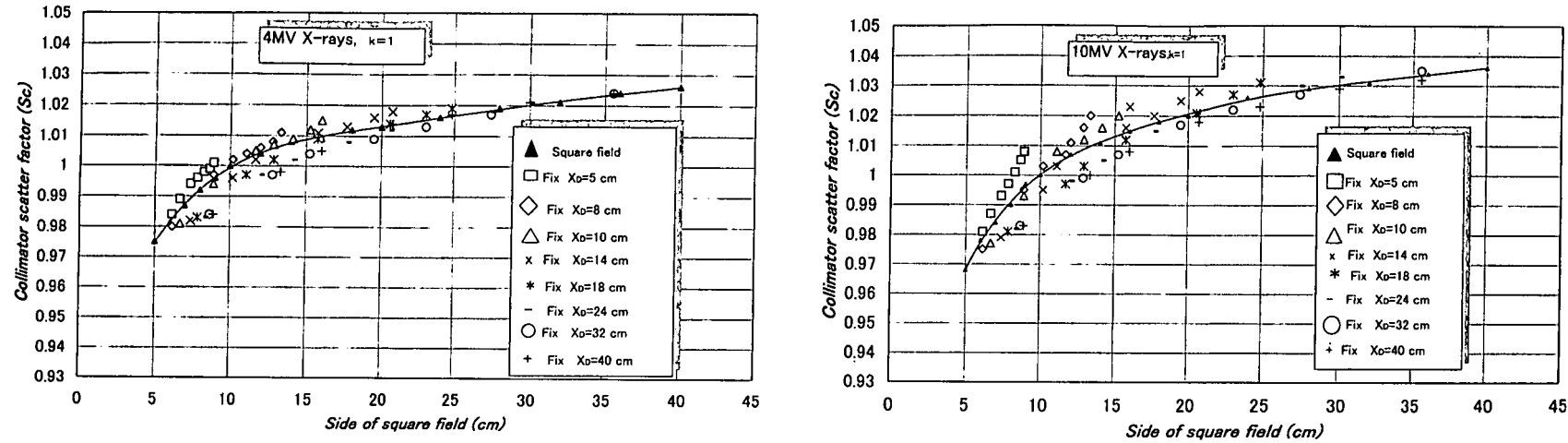

Fig. 3 Sets of (a) $4 \mathrm{MV}$ and (b) $10 \mathrm{MV} \mathrm{X}$-ray collimator scatter factors $\left(S_{c}\right)$ for equivalent square fields obtained using the A/P method $(k=1)$. Black triangles are for square fields (the solid curve was drawn using a polynomial expression created using the Sc data). The other sets of symbols are for rectangular fields, where the $X$ jaw is fixed for each set.
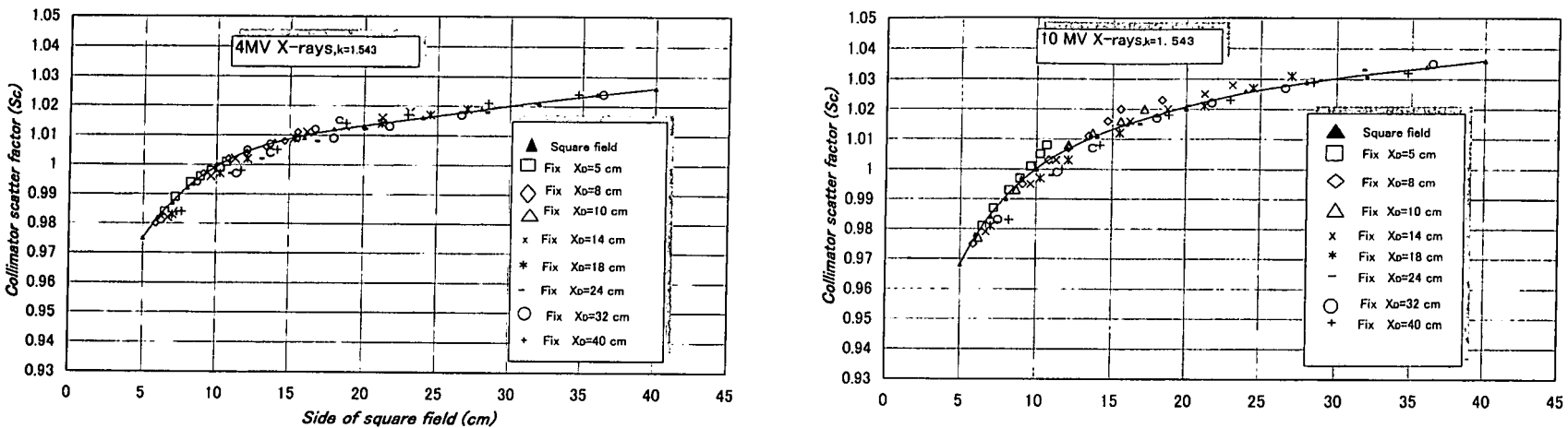

Fig. 4 Sets of (a) $4 \mathrm{MV}$ and (b) $10 \mathrm{MV} X$-ray collimator scatter factors $\left(S_{c}\right)$ for equivalent square fields produced using the field mapping method $(k=1.543)$ proposed by Kim. Black triangles are for square fields (the solid curve was drawn using a polynomial expression created using the Sc data). The other sets of symbols are for rectangular fields, where the $X$ jaw is fixed for each set.
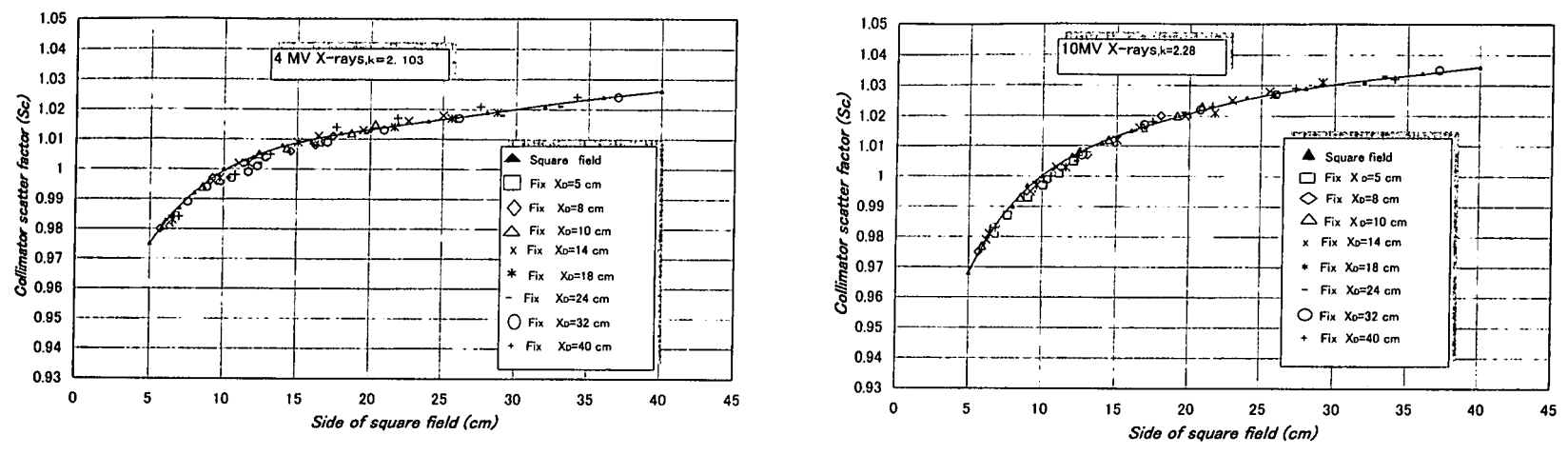

Fig. 5 Sets of (a) $4 \mathrm{MV}$ and (b) $10 \mathrm{MV} X$-ray collimator scatter factors $\left(S_{c}\right)$ for equivalent square fields obtained using the field mapping method with the most suitable $\mathrm{k}$-values $(k=2.103$ for $4 \mathrm{MV} X$-rays and $k=2.280$ for $10 \mathrm{MV} X$-rays). Black triangles are for square fields (the solid curve was drawn using a polynomial expression created using the Sc data). The other sets of symbols are for rectangular fields, where the $X$ jaw is fixed for each set. 

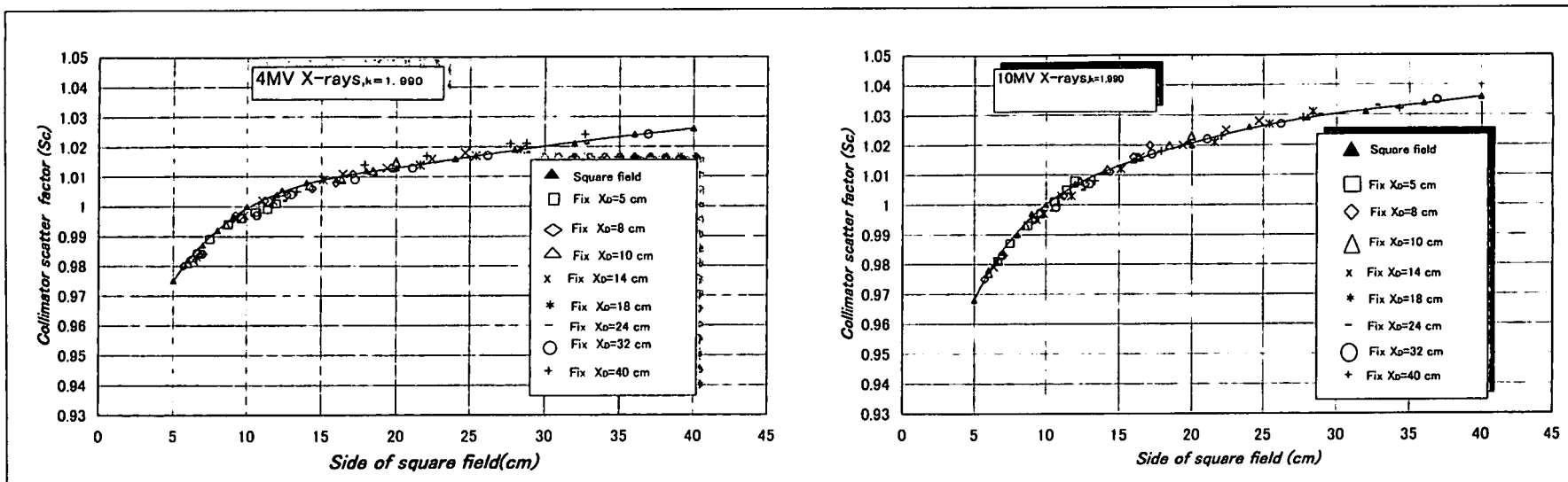

Fig. 6 Sets of (a) $4 \mathrm{MV}$ and (b) $10 \mathrm{MV} X$-ray collimator scatter factors $\left(S_{c}\right)$ for equivalent square fields produced using the field mapping method proposed by Kim, where $k=1.990$, derived using the concept of extra-focal radiation. Black triangles are for square fields (the solid curve was drawn using a polynomial expression created using the Sc data). The other sets of symbols are for rectangular fields, where the $X$ jaw is fixed for each set.

リメータ，平坦化フィルタなど)から散乱線が放出さ れる。最近はこの散乱線をExtra-focal radiation ${ }^{12)}$ と呼 んでいる．散乱線が最も多く放出するのが平坦化フィ ルタなので，これを第 2 線源とする考え方がある．平 坦化フィルタ/上下段コリメータ/検出器の幾何学的位 置関係から求めた $k$ 值は $k=1.990$ になる (Fig. 1参照). この值は，コリメー夕散乱係数 $\left(S_{c}\right)$ 測定データに基づ いて決めた $k$ 值 $(4 \mathrm{MV} \mathrm{X}$ 線では $k=2.103,10 \mathrm{MV} \mathrm{X}$ 線で は $k=2.280) に$ 近いことが判る.このことは, 平坦化フ イルタを第 2 線源とする考え方が妥当であることが理 解される。

$k$ 値に $k=1.990$ を用いた計算結果 (Fig. 6 (a)，（b)参照) では，実線の正方形照射野コリメー夕散乱係数 $\left(S_{c}\right)$ に 対して $4 \mathrm{MV}$ X線での等価照射野変換後のコリメータ 散乱係数 $\left(S_{c}\right)$ の相対誤差は-0.29\%から $0.44 \%$ に分布 し, $10 \mathrm{MV} \mathrm{X}$ 線での等価照射野変換後のコリメー夕散 乱係数 $\left(S_{c}\right)$ の相対詿差は-0.33\%から0.46\%に分布して いる. 4MV X線に関しては, $k=1.990$ (平坦化フィル夕 位置を用いた照射野マッピング法)を用いた場合の方 が $k=2.103$ ( $S_{c}$ 測定データに基づいて決めた值)を用いた 場合より，相対誤差の最小值，最大值だけを比較する と, わずかであるが計算精度が高くなる結果になっ た.

\section{4. 結 論}

コリメータ散乱係数 $\left(S_{c}\right)$ の測定に関しては，ミニフ アントム(アクリル製)を利用した場合，電離箱軸をX 線ビーム軸に対して平行および垂直配置にして求めた $S_{c}$ データ間に有意な差は認められなかった。アルミま たはアクリル製ビルドアップキャップを用いた場合に は，電離箱軸をX線ビーム軸に対して平行配置にする
と，混入電子の影響を抑える効果があると推測され た.

$4 \mathrm{MV}$ おび10MV X線のコリメー夕散乱係数 $\left(S_{c}\right)$ に 関して, 矩形照射野を等価正方形照射野に変換する 3 方法を考察し, 次の結論が得られた。

(1) 照射ヘッドの内部構造を考慮しなければならない 場合にはA/P法は必ずしも精度の優れた方法では ない.

(2) 照射野マッピング法で, extra-focal radiationの概 念で捉えた第 2 線源(平坦化フィルタ)の位置関係 から求めた幾何学的荷重係数 $(k)$ は精度の高い結 果を導く.

（3）照射野マッピング法で，幾何学的荷重係数 $(k)$ を コリメータ散乱係数 $\left(S_{c}\right)$ の測定データに基づいて 決めると, 概して最も高い結果を導く.

\section{付録A：上下段コリメータがモニタ電離箱へ与える影 響}

Duzenliら ${ }^{13)}$ の提案したピンホール法を用いて，上 下段コリメータからの後方散乱がモニタ電離箱に与え る影響の度合いを調べた ${ }^{6)}$. その実験配置をFig.7に 表す。この実験配置ではおもに線源および平坦化フィ ルタからのX線出力の測定を目標にしているので, 上 下段コリメータからの後方散乱がモニタ電離箱へ与え るの影響の度合いが判明する。

4MVおよび10MV X線に対するコリメー夕散乱係数 $\left(S_{c}\right)$ の結果をFig. 8(a)およびFig. 8(b)に示す.ただ し, これらのデータは放射線検出器位置で $40 \times 40 \mathrm{~cm}^{2}$ の正方形照射野を作るコリメー夕開度で得られるコリ メータ散乱係数 $\left(S_{c}\right)$ を基準にして作った。 これにより $4 \mathrm{MV}$ および10MV X線双方に対して次のことが判明 


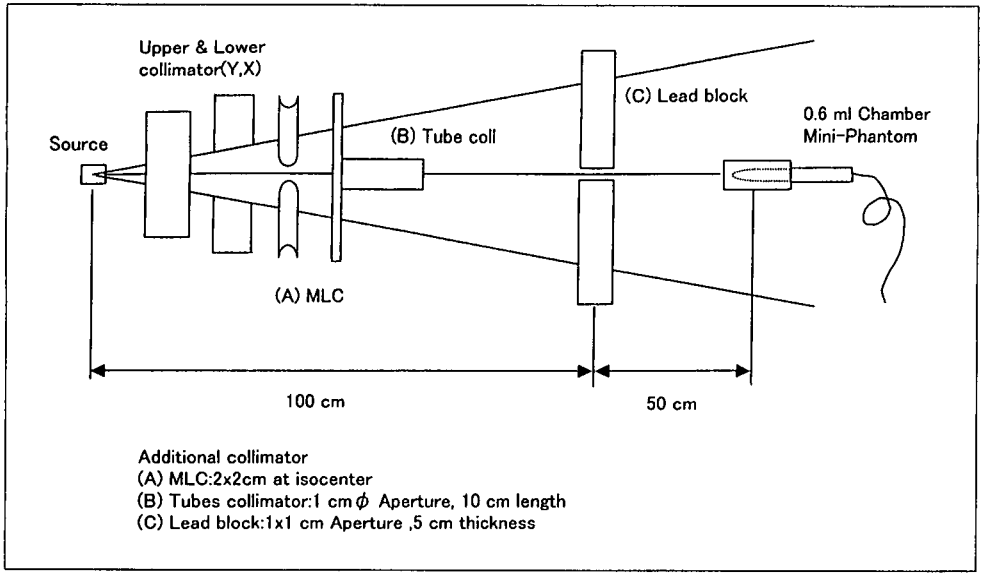

Fig. 7 Schematic diagram (pinhole method) used for evaluating the effect of backscatter from the upper and lower collimators $(\mathrm{Y}$ and $\mathrm{X}$ ) on the monitor chamber.
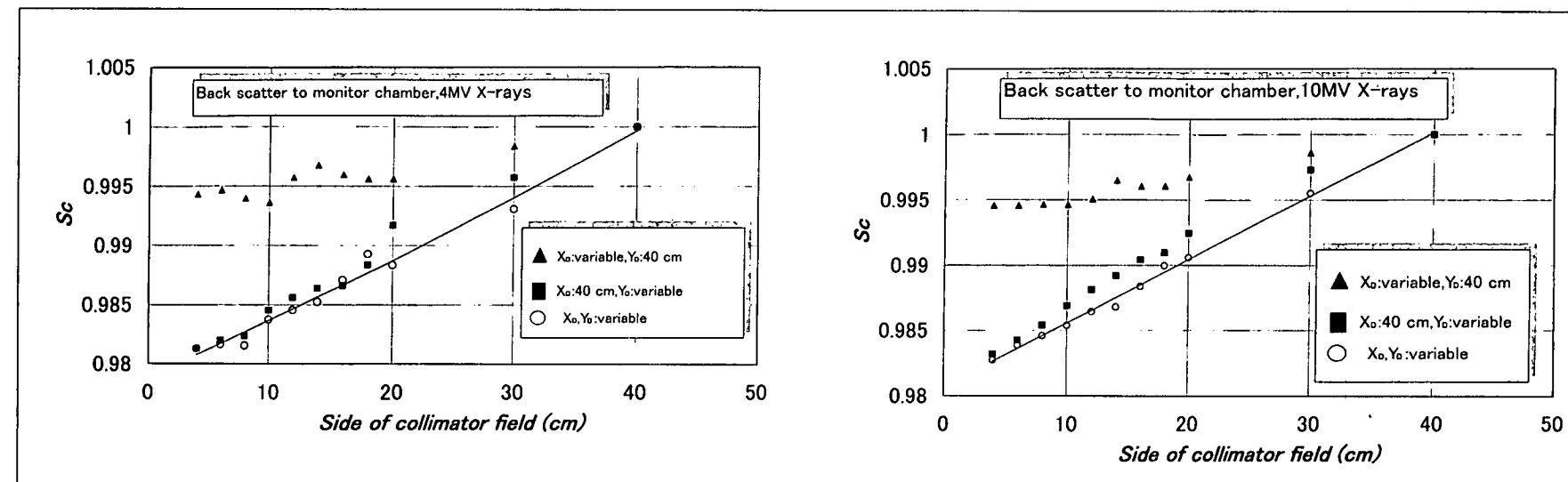

Fig. 8 (a) $4 \mathrm{MV}$ and (b) $10 \mathrm{MV} \mathrm{X}$-ray collimator scatter factors $\left(S_{c}\right)$ with both or each of the upper and lower collimators $(Y$ and $X$ ) being variable, obtained using the pinhole method. Black triangles represent data obtained with $Y_{D}=40 \mathrm{~cm}$ (constant) and $X_{D}=$ variable. Black squares were obtained with $X_{D}=40 \mathrm{~cm}$ (constant) and $Y_{D}=$ variable. White circles were obtained with $Y_{D}=X_{D}=$ variable (the solid curve was drawn using a polynomial expression created using the Sc data).

した.

（1）下段コリメータ（X)による照射野辺を $X_{D}=40 \mathrm{~cm}$ 一 定にしたデータ(ロ印)は正方形照射野データ（○ 印）と殆ど一致する。

（2）上段コリメータ（Y）による照射野辺を $\mathrm{Y}_{\mathrm{D}}=40 \mathrm{~cm}$ 一定にしたデータ (ム印)は下段コリメータ $(\mathrm{X}) に$ よる照射野辺の変化に対してほとんど影響を受け ない.

照射野辺 $4 \mathrm{~cm}$ においてム印の值はロ印の值に比し て，4MV X線の場合約 $1.9 \% ， 10 \mathrm{MV} \mathrm{X}$ 線の場合約 1.7 \%それぞれ高い.このことは照射野辺 $4 \mathrm{~cm}$ において

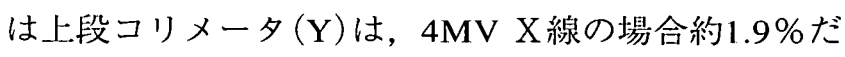
け，10MV X線の場合約1.7\%だけそれぞれモニ夕電離 箱へ余分に影響を及ぼすことが理解される。10×10 $\mathrm{cm}^{2}$ の照射野を規準とするコリメー夕散乱係数 $\left(S_{c}\right)$ で は，4MVおよび10MV X線照射双方において，モニ夕 電離箱は最大約 1 \%だけ上段コリメータ $(\mathrm{Y})$ にっって 影響を受けていることになる。このことはモニタユニ ット $(\mathrm{MU})$ 線量計の上下段コリメータによる影響は最 大 $1 \%$ となるが，通常使用する照射野 $30 \times 30 \mathrm{~cm}^{2}$ 以下 では土0.5\%となる.よって, 上下段コリメータがモニ 夕電離箱に与える影響は一般に無視できる。 


\section{参考文献}

1) Holt JG, Laughlin JS and Moroney JP: The extension of the concept of tissue-air ratios (TAR) to high-energy $x$-ray beams. Radiology, 96, 437-446, (1970).

2) Khan FM, Sewchand W, Lee J, et al.: Revision of tissuemaximum ratio and scatter-maximum ratio concepts for cobalt 60 and Higher x-rays beams. Med. Phys., 7 (3), 230-237, (1980).

3) Van Gasteren JJM, Heukeloma S, Van Kleffens HJ, et al.: The determination of phantom and collimator scatter components of the output of mega voltage photon beams: measurement of the collimator scatter part with a beam-coaxial narrow cylindrical phantom. Radiotherapy and Oncology, 20, 250-257, (1991).

4) IAEA: Absorbed dose determination in phantom and electron beams.IAEA Technical Reports Series 277. pp. 27-29, (1987).

5）中川政萃, 中田 学, 矢野慎輔, 他：ミニファントムを用 いたヘッド散乱係数の測定法の評価. 日放技学誌，56(9)， 1155-1162,(2000).

6）中田 学：第54回総会学術大会シンポジュウムII. 放射線治 㙩における出力測定の物理的問題. 日放技学誌, 55(3),
247-250, (1999).

7) 保科正夫：直線加速器での線量計算におけるX線の出力線 量の評洒. 日放技学誌, 56(4), 559-571,(2000).

8) Kim S, Zhu TC and Palta JR: An equivalent square field formula for determining head scatter factors of rectangular fields. Med. Phys., 24, 1770-1774,(1997).

9) 森川賀根雄：治療用電子ビームの特性一長方形照射野のビ 一ムラメーター。日放技師会雑誌，40(7)，854-863， (1993).

10) Frye DMD, Paliwal BR, Thomadsen BR, et al.: Inter - comparison of normalized head - scatter factor measurement techniqes. Med. Phys., 22(2), 249-253, (1995).

11) Vadash $P$ and Bjärngard BE: An equivalent - square formula for head - scatter factors. Med. Phys., 20(3), 733-734, (1993).

12) Yu MK and Sloboda R:Analytical representation of head scatter factors for shaped photon beams usion a two-componett x-ray source model. Med. Phys., 23 (6), 973-9874, (1996).

13) Duzenli C,Mccleam B and Field C: Backscatter into the beam monitor chamber: Implication for dosimetry of asymmetric collimators. Med. Phys., 20(2), 363-367, (1993).

\section{図表の説明}

Fig. 1上下段コリメー夕絞りによる線源面への逆投影面積の違いを示す模式図.

Fig. 2 ミニファントムおよびビルドアップキャップを用いてコリメータ散乱係数 $\left(S_{c}\right)$ を測定する幾何学的配置図. 検出器軸はX線 ビーム軸に対して (a)平行, (b)垂直.

Fig. 3 A/P法で補正した等価正方形照射野に対するコリメー夕散乱係数 $\left(S_{c}\right)$. 黑三角( $(\boldsymbol{\Delta})$ 印は正方形照射野に対する值(実線はそ れらを多項式で表したもの)。ほかの記号は下段コリメータを固定し，それぞれ上段コリメータを矩形照射野.(a) $4 \mathrm{MVX}$ 線, (b) $10 \mathrm{MV} \mathrm{X}$ 線.

Fig. 4 Kimの照射野マッピング法で補正した等価正方形照射野に対するコリメー夕散乱係数 $\left(S_{c}\right)$. 黑三角(A)印は正方形照射野に 対する值(実線はそれらを多項式で表したもの)。ほかの記号は下段コリメータを固定し, それぞれ上段コリメータを矩形 照射野．（a) $4 \mathrm{MV} X$ 線，（b) 10MV X線.

Fig. 5 照射野マッピング法でk值に最適な值を採用した場合の等価正方形照射野の算出．黑三角(ム)印は正方形照射野に対する值 (奉線はそれらを多項式で表したもの). ほかの記号は下段コリメータを固定し、それぞれ上段コリメータを矩形照射野.

(a) $4 \mathrm{MV} \mathrm{X}$ 線，（b)10MV X線.

Fig. 6 Kimの照射野マッピング法において, extra-focal radiationの概念を用いて得たk值で補正した等価正方形照射野に対するコ リメータ散乱係数 $\left(S_{c}\right)$. 黑三角(A)印は正方形照射野に対する值(実線はそれらを多項式で表したもの)。ほかの㷉号は下段 コリメータを固定し，それぞれ上段コリメータを矩形照射野．（a)4MV X線，(b) $10 \mathrm{MVX}$ X線.

Fig. 7 上下段コリメータ（Y，X)からの後方散乱がモニタ電離箱に与える影郬を測定するための配置図(ピンホール法).

Fig. 8 ピンホール法において, 上段コリメータ（Y)，下段コリメータ（X)の双方または一方を变えた場合のコリメータ散乱係数

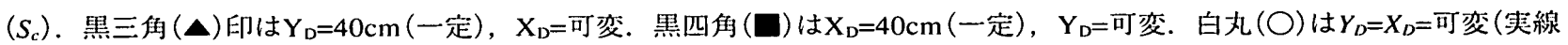
はそれらを多項式で表したもの)。（a)4MV X線，（b)10MV X線.

Table 1 ミニファントム(アクリル製)，アルミ製ビルドアップキャップ，アクリル製ビルドアップキャップを用いて得られた4MV $\mathrm{X}$ 線のコリメータ散乱係数 $\left(S_{\mathrm{c}}\right)$ 。線量計軸はX線ビーム軸に対して (a)平行，（b)垂直.

Table 2 ミニファントム(アクリル製)，アルミ製ビルドアップキャップ, アクリル製ビルドアップキャップを用いて得られた10MV $\mathrm{X}$ 線のコリメータ散乱係数 $\left(S_{c}\right)$. 線量計軸はX線ビーム軸に対して (a)平行, (b) 垂直.

Table 3 ミニファントム法による $4 \mathrm{MV} \mathrm{X}$ 線の上下段コリメータを変化させた場合のコリメー夕散乱係数 $\left(S_{c}\right)$.

Table 4 ミニファントム法による10MV X線の上下段コリメータを変化させた場合のコリメータ散乱係数 $\left(S_{c}\right)$. 